\title{
SOCIAL AND SECURITY IMPACT OF COVID-19 OUTBREAK IN WEST KALIMANTAN BASED ON THE POLICE LAW PERSPECTIVE
}

\author{
Yusuf Setyadi \\ National Police Headquarters of Republic of Indonesia \\ Jl. Trunojoyo No. 3 Kebayoran Baru Jakarta Selatan \\ Email: yusuf setyadi45@yahoo.co.id
}

\begin{abstract}
Abstrak: Ada dilema dalam pelaksanaan social distancing sebagai program kebijakan pemerintah untuk berdiam di rumah saja. Dalam menyikapi dilema tersebut, penulis menganalisis dalam perspektif hukum kepolisian. yaitu peran Polri dalam mengatasi permasalahan selama diberlakukannya peraturan pemerintah. Kajian dilakukan dengan menggunakan data primer dan data sekunder. Data primer didapatkan melalui pengamatan (observasi) dan wawancara di lapangan, sedangkan data sekunder didapatkan melalu penelitian kepustakaan. Data tersebut selanjutnya dianalisis secara kualitatif dan disajikan secara deskriptif. Dari hasil pembahasan disimpulkan bahwa dampak wabah Covid-19 di wilayah Provinsi Kalimantan Barat relatif aman dan terkendali dengan baik yang ditandai dengan tidak ada kejahatan luar biasa. Polri telah melakukan tugasnya dalam segala aspek baik dalam aspek pemeliharaan keamanan dan ketertiban masyarakat, dalam aspek penegakkan hukum, dan dalam aspek perlindungan, pengayoman dan pelayanan kepada masyarakat.
\end{abstract}

Kata Kunci: Sosial, Keamanan; Hukum, Kepolisian.

Abstract: There is a dilemma in implementing social distancing as a government policy program to stay at home. For this, the author analyzed the police law perspective, especially the role of the National Police in overcoming the problems during the enactment of government regulations. The study was conducted using primary and secondary data. Primary data obtained through observation and interview, while secondary data obtained through library research. The data was then analyzed qualitatively and presented descriptively. From the results, it was concluded that the impact of the Covid-19 outbreak in the area of West Kalimantan Province was relatively safe and well-controlled which was indicated by no extraordinary crimes there. Polices had carried out their duties in all aspects both in maintaining security and public, law enforcement, protection, guard, and community services.

Keywords: Police Law Perspective; Social and Security Impacts; Main Duties of Police.

\section{INTRODUCTION}

The coronavirus outbreak in Wuhan, China started in December 2019. In Wuhan the impact was extraordinary. Many victims were infected quickly. Finally, the Chinese government decided to have lockdown by closing the city from all kinds of human 
15 | Yusuf Setyadi, Social and Security Impact..., hlm. 13-26

activity. Only security and health services

infected patients showed serious were there to clean the city. They cleaned symptoms, some even experienced mild the streets and all public facilities by using disinfectants to kill the coronavirus, so that it could break the chain of transmission.

According to Wikipedia data ${ }^{1}$ for March $11^{\text {th }}, 2020$ to April $23^{\text {rd }}, 2020$ had been more than 2,000,000 Covid-19 cases reported in more than 210 countries and regions. It resulted in more than 195,755 people were died and more than 781,109 people were cured. The hypotheses of the experts were correct that the coronavirus (Covid-19) would spread to other countries because human activities from China to other countries could not be avoided. ${ }^{2}$ As a result, it was getting larger to hundreds of countries infected by the coronavirus, including Indonesia. ${ }^{3}$

Moreover, tirto.id ${ }^{4}$ mentioned that this virus was dangerous because not all

\footnotetext{
1 Wikipedia Free Encyclopedia, accessed on March $21^{\text {st }}, 2020.4$

2 Michael Böhm et al., "Coronavirus Disease 2019 (COVID-19) and Its Implications for Cardiovascular Care: Expert Document from the German Cardiac Society and the World Heart Federation," Clinical Research in Cardiology, 2020, 1; Mohammad M. Sajadi et al., "Temperature, Humidity, and Latitude Analysis to Estimate Potential Spread and Seasonality of Coronavirus Disease 2019 (COVID-19)," J AMA Network Open 3, no. 6 (2020): e2011834-e2011834.

${ }^{3}$ Dumilah Ayuningtyas et al., "Local Initiatives In Preventing Coronavirus Based On Health Policy Perceptive," Journal of Indonesian Health Policy and Administration 5, no. 2 (2020).

4 https://tirto.id/bahaya-virus-corona-covid-19dan-cara-mencegahnya-eKdF, accessed on March $21^{\text {st }}, 2020$.
} symptoms or called a silent carrier. The silent carrier was difficult to detect because it could only be known through full inspection. ${ }^{5}$ While those who did not show symptoms may think that he was healthy and became active as usual. Though, he could transmit the coronavirus to others, both at his home or other general public, so that the spread may become larger. ${ }^{6}$

In Indonesia, the development of the coronavirus (Covid-19) almost infected entire provinces with a significant number of fatalities. ${ }^{7}$ Therefore, Indonesia was in emergency status by prioritizing social and physical distancing programs. ${ }^{8}$ Considering the high level of spread was difficult to control, the government had implemented PSBB (Large-Scale Social Restrictions) in accordance with Government Regulation

\footnotetext{
5 Pooja Dewan and Piyush Gupta, "Pediatric COVID-19: The Silent Spreaders Are Not so Silent Anymore," Annals of the National Academy of Medical Sciences (India), 2020.

${ }^{6}$ Claudio Guarneri et al., "Silent COVID-19: What Your Skin Can Reveal," The Lancet Infectious Diseases, 2020; Kyle R. Ringenberg et al., "Protection of Anesthesia Providers from Silent Carriers of COVID-19 While Minimizing Disposable PPE Utilization," Journal of Clinical Anesthesia 66 (2020): 109930.

7 Riyanti Djalante et al., "Review and Analysis of Current Responses to COVID-19 in Indonesia: Period of January to March 2020," Progress in Disaster Science, 2020, 100091.

8 Presidential Decrees No. 11 of 2020
} 
No. 21 of 2020 concerning Large-Scale Social Restrictions in the Context of Accelerating the Handling of Coronavirus Disease 2019 (Covid-19). ${ }^{9}$

Based on those facts, this article was aimed to discuss the social and security impacts of the Covid-19 outbreak in West Kalimantan based on the Police Law perspective. This paper was focused on answering two problems: 1) What were the social and security impacts caused by the covid-19 outbreak ?; 2) What were the roles of the police in dealing with social and security impacts of the covid-19 outbreak in West Kalimantan?

\section{METHOD}

The study was conducted using primary and secondary data, in which primary data was obtained through observations and secondary data was obtained through library research. ${ }^{10}$ The data was analyzed qualitatively and presented descriptively.

\section{RESULTS AND DISCUSSION}

Etymologically, the term "police" was first discovered in Greek as politeia. In the United Kingdom, the word "police" was also known as constable, in Germany as

\footnotetext{
${ }^{9}$ Government Regulation No. 21 of 2020

10 Barbara M. Wildemuth, Applications of Social Research Methods to Questions in Information and Library Science, 2nd Edition (ABC-CLIO, 2016).

11 Bernadeta Nowak, "Historical and Political-Legal Aspects of Polish Police Activity as a Part of the Public Security System," Політичне Житmя, nо. 4 (2018): 31-36.
}

Polizei, in America as sheriffs, in Dutch as Holland, in Japan as koban and chuzaisho (even though the term koban was a name of a police station in an urban area and chuzaisho was a police station in a rural area). ${ }^{11}$ The word politeia was used in the title of Plato's first book, which implied an ideal country, a country free from its greedy and evil leaders, where justice was high esteem. ${ }^{12}$ Then, it came to be known as a form of a police state (polizeistaat) which means a state that carried out security and prosperity, even though this police state was controlled absolutely.

In Indonesia, there were two concepts about the police. It was sicherheit polizei as a guardian of code of conduct and security, and verwaltung polizei or woblfart polizei as a manager of an economy or all citizens' living needs. ${ }^{13}$ Indonesia seemed to follow and use the term "politie" in Dutch. This was an influence of the Dutch legal system adopted in Indonesia. According to Van Vollenhoven in his book "Politei Overzee" as quoted by Kelana ${ }^{14}$ the term "politei" implied an organ and function, which was a governmental organ to supervise, if necessary using coercion so that the

\footnotetext{
12 Alun Howard Gibbs, "The Horizons of the Constitution: Politeia, the Political Regime and the Good," Law and Critique 27, no. 1 (2016): 83.

13 Sadjijono, Memahami Hukum Kepolisian (Surabaya: Laksbang, 2009), 1. \{Citation\}

14 Momo Kelana, Hukum Kepolisian (Jakarta: PT Grasindo, 1994), 6.
} 
subordinates would obey all the orders. ${ }^{15}$ Based on this understanding, the police were government organs (regeeringorganen) who were given the authority and obligations to do supervision. Thus, the term "police" could be interpreted as a part of a government organization and as its instrument. ${ }^{16}$

The police department carried out its duties and responsibilities by accomplishing the main tasks according to its functions. Its main tasks were maintaining and ordering the public, enforcing the law, providing protection, and giving community services. The main tasks of the Indonesian National Police were regulated in Law article 13 No. 2 of 2002 concerning the National Police. ${ }^{17}$ The tasks were classified into three: Maintaining public security and order; Upholding the law; Providing protection, guard, and community services. ${ }^{18}$

In maintaining public order and security, the National Police had the responsibility of creating and maintaining a safe condition for the public. According to

15 Pudi Rahardi, Hukum Kepolisian, Kemandirian, Profesionalisme Dan Reformasi Polri (Surabaya: Laksbang Garfika, 2014), 2.

${ }^{16}$ Sadjijono, Memahami Hukum Kepolisian, 2.

17 Anton Suryadi, "Fungsi Patroli Polisi Dalam Penanggulangan Tindak Pidana Kejahatan Menurut Undang-Undang Nomor 2 Tahun 2002 Tentang Kepolisian Negara Republik Indonesia," Gema Genggong: Jurnal Hukum, Keadilan \& Budaya 1, no. 1 (2017).

18 Muhammad Guntur, "Fungsi Kepolisian Negara Dalam Pemeliharaan Keamanan Dan Ketertiban
Soebroto ${ }^{19}$ security and orderliness was a condition free from damage or destruction which threatened the people or a person and provided a sense of freedom from fear or worry, so that there were a certainty and a guarantee to free from violations of norms. ${ }^{20}$ This task could be accomplished preventively and repressively. Preventive tasks were done by protecting people's activities to avoid criminogenic factors developed to police hazard as a factual threat. It could be formulated if intentions and opportunities met, a crime would appear $(\mathrm{n}+\mathrm{k}=\mathrm{c})$. Therefore, it should be prevention to avoid the meeting of intentions and agreements to do evil, so there would be no crime. ${ }^{21}$

The police were called as law enforcement. Consequently, the police must know the law. Not only know it but also must have the ability to master the law in all aspects. Also, the police must follow the law, so all the actions could be rechmatig. ${ }^{22}$ The International City Manager Association wrote that the entire

Pada Masyarakat Kota Sengkang Kabupaten Wajo," Al Hikam 1, no. 3 (2017): 64.

${ }^{19}$ Soebroto Brotodiredjo in R. Abdussalam, Penegak Hukum Di Lapangan Oleh Polri Jakarta: Dinas Hukum Polri, 1997), 22.

20 Guntur, "Fungsi Kepolisian Negara Dalam Pemeliharaan Keamanan Dan Ketertiban Pada Masyarakat Kota Sengkang Kabupaten Wajo."

${ }^{21}$ Sadjijono, Memahami Hukum Kepolisian, 111.

${ }^{22}$ Momo Kelana, Hukum Kepolisian, 7. 
governance framework was built on law, order and depended on honest and efficient police administration. It seemed that this immediately gave enormous responsibility on the shoulders of police officers. ${ }^{23}$ According to Law No. 2 of 2002 in article 18 explained that the police were given authority ${ }^{24}$ in certain circumstances to act according to his judgment as to the power of functional discretion which placed the police as a central factor in the law enforcement. ${ }^{25}$ In carrying out their duties the National Police could encounter a dilemma. On the one hand, they were committed to upholding the rule of law, but on the other hand public awareness for the law was still very low. ${ }^{26}$

In this Covid-19 outbreak condition, the law used by police officers in carrying out their duties referred to special criminal law and general criminal law. For people who were obstructing police duties related to the Police Chief's Declaration, they would get a police action as regulated in special criminal law for handling the spread of the Covid-19 outbreak referring to the health law. Special Criminal Law: ${ }^{27}$

1. Legal Framework: Law No. 4 of 1984 on Epidemics

\footnotetext{
23 Siswanto Sunarso, Pengantar Ilmu Kepolisian (Jakarta: Pustaka Perdamaian Nusantara, 2015), 5.

24 Farouk Muhammad, Menuju Reformasi Polri (Jakarta: PTIK Press, 2008), 104-5.

${ }^{25}$ Yoyok Ucuk Suyono, Hukum Kepolisian; Kedudukan Polri Dalam Sistem Ketatanegaraan Indonesia Setelah
}

Article 14 paragraph (1):

"Anyone who intentionally obstructing the efforts to control the spread of epidemics as regulated in this Law is threatened with imprisonment for up to 1 (one) year and/or a maximum fine of Rp 1,000,000 (one million rupiahs)."

Article 14 paragraph (2):

"Anyone due to his absence obstructing the efforts to control the spread of epidemics as regulated in this Law is threatened with imprisonment for a maximum of 6 (six) months and/or a maximum fine of $\mathrm{Rp} 500,000$ (five hundred thousand rupiahs)."

2. Legal Framework Law No. 6 of 2018 concerning Health Quarantine.

Article 59

(1) Large-scale social restrictions are part of the Public Health Emergency Response.

(2) Large-scale social restrictions are aimed to prevent the spread of epidemics in a certain area.

(3) Large-scale social restrictions in paragraph (1) at least include:

a. No school and workplace Activities;
Perubahan UUD 1945 (Yogyakarta: Laksbang Grafika, 2013), 148.

${ }^{26}$ Farouk Muhammad, Menuju Reformasi Polri, 107.

${ }^{27}$ Sukanda Husin, "Peranan Hukum Pidana Dalam Memerangi Kejahatan Lingkungan Di Indonesia," Jurnal Hukum \& Pembangunan 25, no. 6 (2017): 501513. 
19 | Yusuf Setyadi, Social and Security Impact..., hlm. 13-26

b. Limitation of religious activities; and/or

c. Limitation of public activities.

(4) The implementation of large-scale social restrictions is coordinated with some related parties appropriate to the provisions.

Article 93

"Anyone who disobeys the implementation of Health Quarantine as referred in Article 9 paragraph (1) and/or obstructs the operation of Health Quarantine causing Public Health Emergency is sentenced to a maximum of 1 (one) year imprisonment and/or a maximum fine of Rp.100,000,000.00 (one hundred million rupiahs)."

3. Legal Framework Law No. 36 of 2009 concerning Health

Article 152 paragraph (1) and (2)

"The government, regional government, and the society are responsible for the prevention, control, and eradication of the infectious diseases, and its consequences to protect the society from the disease infection, to reduce the number of infection, disablement and/or fatality, and the social and economic impacts from the contagion."

4. Police Chief Declaration No. $\mathrm{Mak} / 2 / \mathrm{III} / 2020$

"Point 3 states that if a contrary act is found, every member of the Indonesian National Police is required to take the necessary police actions based on the Indonesian National Police Chief's declaration that authorizes the National Police member to accomplish their duties in the Covid-19 outbreak condition by applying the provisions of general and special criminal law." 28

\section{General Criminal Law}

1. Criminal Code Article 212 mentions: ${ }^{29}$

"Anyone with violence or threat against an official who is carrying out a legitimate duty or anyone who according to legal requirements or through the official's request gives help to him is threatened because he is against the official with a maximum imprisonment of one year and four months or a maximum fine of four thousand five hundred rupiahs."

Related to Criminal Code Article 214, if it is done by two people or more, the

\footnotetext{
28 Nur Rohim Yunus, "Kebijakan Covid-19, Bebaskan Narapidana Dan Pidanakan Pelanggar PSBB," 'ADALAH 4, no. 1 (2020); Putu Sekarwangi Saraswati, "Kebijakan Hukum Terhadap Penanganan Pandemi Covid-19 Di Indonesia," KERTHA WICAKSANA 14, no. 2 (2020): 147152.
}

\footnotetext{
${ }^{29}$ Opik Rozikin, "CONTEMPT OF COURT IN INDONESIAN REGULATION," CIC Lembaga Riset Dan Konsultan Sosial 1, no. 1 (2019): 1-16; Prima Rianto Hutagaol and Ledy Diana, "Penegakan Hukum Terhadap Masyarakat Yang Melakukan Tindak Pidana Melawan Aparat Yang Sedang Bertugas Oleh Kepolisian Resor Simalungun" (PhD Thesis, Riau University, 2016).
} 
maximum imprisonment number is seven years.

2. Article 216 paragraph (1) mentions:

"Anyone who intentionally does not obey appropriate orders or requests from officials whose job is to supervise something, or by officials based on their duties, as well as those who are authorized to investigate criminal acts; likewise, anyone who deliberately prevents, obstructs or thwarts actions to accomplish the provisions of the law by one of the officials, is threatened with imprisonment for up to four months two weeks or a maximum fine of nine thousand rupiahs. "

3. Criminal Code Article 218 mentions: "Anyone who when the people in crowded deliberately not leaving immediately after being ruled three times by or on behalf of the authorities, is threatened with imprisonment for a maximum of four months and two weeks or a maximum fine of nine thousand rupiahs".

A repressive task is conducting investigations for crimes and violations according to the provisions in the Act. This repressive task is the police task in the field of justice or law enforcement. ${ }^{30}$ The main duties of the police, as mentioned in Article

30 Guntur, "Fungsi Kepolisian Negara Dalam Pemeliharaan Keamanan Dan Ketertiban Pada Masyarakat Kota Sengkang Kabupaten Wajo,” 64
13 of Law No. 2 of 2002 concerning the National Police, are then detailed in Article 14, consisting of:

1. Accomplishing the regulations, guarding, escorting, and patrolling to society and government activities as needed;

2. Implementing all activities in ensuring the safety, orderliness and good traffic on the road;

3. Training the society to increase their participation, awareness, and obedience to the laws and regulations;

4. Participating in the development of national law;

5. Maintaining order and public security;

6. Coordinating, supervising, and providing technical assistance to special police, civil servant investigators, and all kinds of self-help security.

7. Investigating all criminal acts based on criminal procedure and other laws and regulations;

8. Organizing police identification, police medicals, forensic laboratories and police psychology for the sake of police service

9. Protecting physics and emotions, goods, society, and nature from the disruption of order and/or disaster, including

67. See also the provisions of article 13 and article 14 of Law no. 2 of 2002 concerning the Indonesian National Police. 
21 | Yusuf Setyadi, Social and Security Impact..., hlm. 13-26

providing assistance and help by according to their beliefs. Consequently, the upholding human rights; muftis who should be role models in

10.Serving the society for a while before handling the Covid-19 outbreak were split being handled by the agency or the authorities

11.Providing services to the society related to their needs within the police duties; and

12.Accomplishing other tasks based on the regulations

The discussion in this article covers the impact of the covid-19 outbreak and how the role of the police in handling it.

\section{The Social and Security Impact of Covid-19 Outbreak}

From observations to the people affected by the Covid-19 outbreak especially the poor and underprivileged, the social impacts caused by the Covid-19 outbreak, especially in the area of West Kalimantan included the pros and cons for praying regulations, a grouping of scholars' opinions, marriages postponing, mosque suspension activities, and economics problems.

First, there were pros and cons in the Islamic community related to the fatwa of the MUI (Indonesian Ulema Council) which recommended doing prayer at home and avoiding prayer at the mosque. There were supported groups and there were refused groups. These differences had no solution so that people continued to pray into two or more groups. In West Kalimantan, the groups were difficult to be united, even though for fighting the Covid19 outbreak required unity. These differences could be seen from the mosque closures for praying in congregations because there were still some mosques that did not close and continued to pray in congregations. This certainly would give negative effect in breaking the chain of the Covid-19 epidemic spread.

The next impact was marriage postponing because of the outbreak. However, some continued to hold the qobul even if the ceremony was postponed. This difference in views was still a matter of debate.

Moreover, there was a concern from the poor related to the government's program to stay at home and do not work. They worried if the did not work, they would not have money for eating and paying their needs like paying for bills, debts, and others.

From the security aspect, based on observations on the complaints from the residents, the impact caused by the Covid19 outbreak, particularly in West Kalimantan, included the increase in conventional crime in residential areas, such as thievery and increasing number of unemployment, the existence of 
irresponsible parties to take advantage of the conditions, the increasing vulnerability level of crimes for various reasons.

Irresponsible parties took an advance on the moment of the Covid-19 outbreak to get a lot of benefits for individuals and groups. These parties raised the price of personal protective equipment, necessities, medicines, and others beyond the reasonable limit prices; consequently, it caused anxiety, the spread of provocative information such as hoaxes, hatred speeches, slander, and conflicts. Then, these made social conflict and security disruption in society.

The crime vulnerability level in the border (Indonesia-Malaysia) was disrupted, due to a lot number of repatriated Indonesian migrant workers in Malaysia, because the Malaysian government implemented a lockdown for the covid-19 outbreak. Foreigners who came to West Kalimantan were temporarily quarantined by the sponsors because there were protests from the locals who worried that the foreigners could bring the Covid-19 outbreak. These people when in Indonesia could be considered as unemployment. Indication of the vulnerability was high because of the unemployments. They did not have money, so they did crimes.

\footnotetext{
31 Bima Anggarasena, "Strategi Penegakan Hukum Dalam Rangka Meningkatkan Keselamatan Lalu Lintas Dan Mewujudkan Masyarakat Patuh Hukum”
}

Moreover, the release of prisoners who had been assimilated by the government through the Correctional Division of the Ministry of Law and Human Rights in West Kalimantan due to Covid-19 had created new problems, because after being released from prison they had committed more crimes.

The Role of The Police in Handling Social and Security Impacts of Covid-19

\section{Outbreak in West Kalimantan}

\section{A. In The Aspect of Maintaining Public \\ Order and Security}

In carrying out the duties of maintaining safety and community order, the Police must show the attitudes and behaviors of maintainers and controllers to the community who were not obedient and disobeyed a general rule. ${ }^{31}$ The presence of the police officers in the public to support government programs in the context of preventing and overcoming the Covid-19 outbreak was done in these steps:

a. Spraying some disinfectants to public facilities and residential areas to prevent the spread of epidemics.

b. Providing information, enlightenment, and suggestions to the public for not making crowded especially in public

(PhD Thesis, UNIVERSITAS DIPONEGORO, 2010). 
23 | Yusuf Setyadi, Social and Security Impact..., hlm. 13-26

places as an effort to carry out social forms. The law enforcement done by the distancing programs.

police officers was to support government

c. Providing suggestions to cafe and programs in the efforts to prevent the restaurant owners to only provide Covid-19 outbreak which included: takeaway services.

d. Giving a warning to people conducting public activities such as wedding receptions, tahlil events, thanksgiving, and others by advising the organizing committee, if it is considered dangerous to immediately be dismissed.

a. Inspecting a cybercrime by controlling hoaxes, hate speeches, provocative speeches, and conflicts in social media that could bring a misleading to the public regarding the Covid-19 pandemic.

b. Taking action against traders who sold

e. Reminding the public through uniformed and non-uniformed police in public places to do self-discipline by using masks and hand sanitizers if they were going outside.

f. Asking the public, especially to young people who often gathered in cafes until late at night to go home and stay at home.

g. Asking people to pray at home not in a congregation, although some people did not follow this suggestion.

h. Patrolling on road to find a crowded, and then encouraged them to return home.

i. Blocking the road to prevent people from transportation services and activities.

\section{B. In The Aspect of Law Enforcement}

The implementation of law enforcement by the Police was done as criminal detectives, both in general and specific

\section{In The Aspect of Protection, Guard, and Community Services}

In the implementation of the aspect of protection, guard, and community services, the roles of the Police were mentioned in the following:

a. Supporting the government program in providing food for the poor affected by the Covid-19 epidemic.

b. Giving the community personal protective equipment (masks, hand sanitizers, and disinfectant) for free.

c. Providing health consultation and socialization to society. 
d. Giving health social services by atmosphere of the Covid-19. In the aspect providing free health services to the of protection, guard, and community society.

e. Providing easy community service service, there was a possibility that the poor through social media to implement social distancing.

did not reach from the government's assistance programs. Therefore, in controlling the spread of the Covid-19

f. Eliminating tax penalties of driving license cards, vehicle registration certificates, and vehicle titles for motorcycle owners.

\section{CONCLUSION}

From the discussion, the author concluded that generally the security situation and social upheaval as the impact of the Covid-19 outbreak in West Kalimantan were relatively safe and wellcontrolled. The indicator was no extraordinary or prominent crimes and large social upheavals on the surface. In the aspect of maintaining public order and security based on observations in the field, it appeared that there were community violations of health protocols such as making crowded and not keeping a distance, wandering, and not staying only at home and other violations. In the aspect of law enforcement from observations, the control of incorrect news had been done, such as hoaxes, hate speeches, slander and so on. Moreover, the police had raided the traders who took an advance from this condition. The prices got higher on the basic needs, medicines, and personal protective equipment needed in the outbreak in West Kalimantan must be well integrated. All parties must contribute to the success of the government's efforts to implement the PSBB (Large-Scale Social Restrictions) by prioritizing the role of police officers in implementing police law to create security and public order.

\section{REFERENCES}

Anggarasena, Bima. "Strategi Penegakan Hukum Dalam Rangka Meningkatkan Keselamatan Lalu Lintas Dan Mewujudkan Masyarakat Patuh Hukum." PhD Thesis, UNIVERSITAS DIPONEGORO, 2010.

Ayuningtyas, Dumilah, Misnaniarti Misnaniarti, Siti Khodijah Parinduri, Fitria Aryani Susanti, Ni Nyoman Dwi Sutrisnawati, and Sayyidatul Munawaroh. "Local Initiatives In Preventing Coronavirus Based On Health Policy Perceptive." Journal of Indonesian Health Policy and Administration 5, no. 2 (2020).

Böhm, Michael, Norbert Frey, Evangelos Giannitsis, Karen Sliwa, and Andreas M. Zeiher. "Coronavirus Disease 2019 (COVID-19) and Its Implications for Cardiovascular Care: Expert Document from the German Cardiac Society and the World Heart Federation." Clinical Research in Cardiology, 2020, 1.

Dewan, Pooja, and Piyush Gupta. "Pediatric COVID-19: The Silent Spreaders Are Not so Silent 
25 | Yusuf Setyadi, Social and Security Impact..., hlm. 13-26

Anymore." Annals of the National Academy of Medical Sciences (India), 2020.

Djalante, Riyanti, Jonatan Lassa, Davin Setiamarga, Choirul Mahfud, Aruminingsih Sudjatma, Mochamad Indrawan, Budi Haryanto, Muhammad Sabaruddin Sinapoy, Irina Rafliana, and Susanti Djalante. "Review and Analysis of Current Responses to COVID-19 in Indonesia: Period of January to March 2020." Progress in Disaster Science, 2020, 100091.

Farouk Muhammad. Menuju Reformasi Polri. Jakarta: PTIK Press, 2008.

Gibbs, Alun Howard. "The Horizons of the Constitution: Politeia, the Political Regime and the Good." Law and Critique 27, no. 1 (2016): 83-102.

Guarneri, Claudio, Emmanuele Venanzi Rullo, Piero Pavone, Massimiliano Berretta, Manuela Ceccarelli, Alfonso Natale, and Giuseppe Nunnari. "Silent COVID-19: What Your Skin Can Reveal." The Lancet Infectious Diseases, 2020.

Guntur, Muhammad. "Fungsi Kepolisian Negara Dalam Pemeliharaan Keamanan Dan Ketertiban Pada Masyarakat Kota Sengkang Kabupaten Wajo.” Al Hikam 1, no. 3 (2017): 64-78.

Husin, Sukanda. "Peranan Hukum Pidana Dalam Memerangi Kejahatan Lingkungan Di Indonesia." Jurnal Hukum \& Pembangunan 25, no. 6 (2017): 501-513.

Hutagaol, Prima Rianto, and Ledy Diana. "Penegakan Hukum Terhadap Masyarakat Yang Melakukan Tindak Pidana Melawan Aparat Yang Sedang Bertugas Oleh Kepolisian Resor Simalungun." PhD Thesis, Riau University, 2016.

Momo Kelana. Hukum Kepolisian. Jakarta: PT Grasindo, 1994.

Nowak, Bernadeta. "Historical and Political-Legal Aspects of Polish Police Activity as a Part of the
Public Security System." Політичне Жumma, no. 4 (2018): 31-36.

Pudi Rahardi. Hukum Kepolisian, Kemandirian, Profesionalisme Dan Reformasi Polri. Surabaya: Laksbang Garfika, 2014.

Ringenberg, Kyle R., Bradley A. Fremming, Steven L. Lisco, and Thomas E. Schulte. "Protection of Anesthesia Providers from Silent Carriers of COVID-19 While Minimizing Disposable PPE Utilization." Journal of Clinical Anesthesia 66 (2020): 109930.

Rozikin, Opik. "CONTEMPT OF COURT IN INDONESIAN REGULATION." CIC Lembaga Riset Dan Konsultan Sosial 1, no. 1 (2019): 1-16.

Sadjijono. Memahami Hukum Kepolisian. Surabaya: Laksbang, 2009.

Sajadi, Mohammad M., Parham Habibzadeh, Augustin Vintzileos, Shervin Shokouhi, Fernando Miralles-Wilhelm, and Anthony Amoroso. "Temperature, Humidity, and Latitude Analysis to Estimate Potential Spread and Seasonality of Coronavirus Disease 2019 (COVID-19)." JAMA Network Open 3, no. 6 (2020): e2011834-e2011834.

Saraswati, Putu Sekarwangi. "Kebijakan Hukum Terhadap Penanganan Pandemi Covid-19 Di Indonesia." KERTHA WICAKSANA 14, no. 2 (2020): 147-152.

Siswanto Sunarso. Pengantar Ilmu Kepolisian. Jakarta: Pustaka Perdamaian Nusantara, 2015.

Soebroto Brotodiredjo in R. Abdussalam. Penegak Hukum Di Lapangan Oleh Polri. Jakarta: Dinas Hukum Polri, 1997.

Suryadi, Anton. "Fungsi Patroli Polisi Dalam Penanggulangan Tindak Pidana Kejahatan Menurut Undang-Undang Nomor 2 Tahun 2002 Tentang Kepolisian Negara Republik Indonesia." Gema 
Genggong: Jurnal Hukum, Keadilan \& Budaya 1, no. 1 (2017).

Wildemuth, Barbara M. Applications of Social Research Methods to Questions in Information and Library Science, 2nd Edition. ABC-CLIO, 2016.

Yoyok Ucuk Suyono. Hukum Kepolisian; Kedudukan Polri Dalam Sistem Ketatanegaraan Indonesia Setelah Perubahan UUD 1945. Yogyakarta: Laksbang Grafika, 2013.

Yunus, Nur Rohim. "Kebijakan Covid-19, Bebaskan Narapidana Dan Pidanakan Pelanggar PSBB." 'ADALAH 4, no. 1 (2020).

\section{RULES OF LAWS}

Law No. 2 of 2002 Concerning Republic of Indonesia Police Department.

Law No. 36 of 2009 Concerning Health

Law No. 4 of 1984 Concerning on Epidemics

Law No. 6 of 2018 Concerning Health Quarantine 